\title{
Research on the Cultivation Path of the Grass-roots Party Construction in Universities under Micro- vision
}

\author{
Shang Yi-jun \\ School of Resource and Environmental Engineering \\ Wuhan University of Technology \\ Wuhan, P.R.China \\ shangyijun723@163.com,
}

\author{
Ma Jia-ming \\ School of Resource and Environmental Engineering \\ Wuhan University of Technology \\ Wuhan, P.R.China \\ 411891489@qq.com,
}

\author{
Guo Na \\ School of Resource and Environmental Engineering \\ Wuhan University of Technology \\ Wuhan, P.R.China \\ 602284777@qq.com
}

\begin{abstract}
The creation process of the brand activities of the party building in universities is to promote the process of the continuous innovation on the concept, form, carrier and mechanism of grass-roots party construction, is the exploration and summary on the inherent law of grass-roots party construction work. In the network "micro" era, it is of great significance to accurately grasp the laws of time and the laws of students growth, to clever integrate brand construction concept into the grassroots party construction in universities and to explore the theory and path of the brand construction of the grass-root party construction under the view of "micro", in order to enhance the scientific level of grassroots party construction in universities, to further strengthen and improve the grass-roots party construction work in universities.
\end{abstract}

Keywords-Microscope; Grass-roots Party Construction in universities; Brand Cultivation

\section{INTRODUCTION}

As a part of campus culture brand, the brand of party construction work is an important part of the construction of college soft power. It is an efficient way on the exploration of strengthening grass-roots party organization construction in an all-round way and an important carrier of the CPC party construction of university innovation under the new situation to innovative the ways and forms of grass-roots party organization construction, actively grasp the help of the construction of cultural soft power, closely integrate with the background of micro times, explore a brand which can build consensus, explore the realization of the scientific development, construct party construction brand in universities.

\section{THE CONNOTATION OF THE BRAND OF THE GRASS-ROOTS PARTY CONSTRUCTION IN THE MICROSCOPE}

In recent years, with the rapid development of Internet technology and communication technology, more and more

The research work is supported by "the Fundamental Research Funds for the Central Universities", and the funding project number is: WUT 2017VI120. things have been dubbed "micro", such as Microblog, We-Chat, Micro-novel, and micro-life, etc. The society has gradually entered the "micro-era". The thinking and methods for people to solve problems are increasingly turning to micro thinking and micro-view ${ }^{[1]}$. Therefore, studies from the perspective of "micro" to explore the brand cultivation path of grass-roots party construction in universities are not only a new exploration and new attempt on the party construction ideas in the new period which closely combines with the era background, but also carves out a new field and new horizon on the party construction theory in the new times, which has very important significance for both theoretical research and practical exploration.

Brand of grass-roots party construction in universities refers to introducing the concept of brand management, combining with the characteristics and features of party construction in universities, exploring new mechanisms and methods of party construction which is conform to the contemporaneity and regularity and full of creations, so as to make it become the important gripper to strengthen and improve college party construction work and become an effective way to continuously improve the scientific level of party construction in universities. It is gradually formed in the university in the process of party construction, through its advanced concepts, innovative ideas, successful working mode and the long tradition of party construction ${ }^{[2]}$. Therefore, it has strong appeal, cohesion and influence, the larger demonstration effects, guiding effects and radiating functions and driving role. It has high sense of identity among the party members and the masses and party construction concept with distinct era characteristics, logo and carrier. It is the comprehensive reflection of the internal quality and external characteristics of party construction in universities and colleges. 


\section{THE VALUE ANALYSIS OF THE BRAND OF THE GRASS-ROOTS PARTY CONSTRUCTION WORK IN UNIVERSITIES}

Brand concept will be implanted into the party construction in universities. To construct the brand of party construction and make it become an important gripper to strengthen and improve the grass-roots party construction work of colleges has the very vital significance on the innovation of party construction and the improvement of the scientific level of party construction in universities $^{[3]}$.

\section{A. It helps to improve the scientific level of party construction in universities}

As a management technology and management thinking of modern management, brand building is of great value to improve the quality of the party construction work in universities. The quality and level of the party construction work in universities is the quality and level of cultivating people. The educational level is mainly reflected in the scientific, pertinence and effectiveness of the method of work ${ }^{[4]}$. Quality is the essence and life of the brand. It is also the basic value orientation of party construction under the new situation. The brand of party construction work without quality will be eliminated by the society and the teachers and students party members. Therefore, the brand construction of party construction work in universities inevitable requires high quality management, high quality service, high quality talent cultivation, and should be reflected and the quality and level of education on the teaching, scientific research and service quality should be improved.

Therefore, based on the concept and management tools of the brand, to construct the brand of grassroots party construction in universities which meets the construction requirement of the party and another party external influence is a new effective way to strengthen and improve party construction in universities, to improve the level of scientific party construction in universities.

\section{B. It is helpful to promote the connotation development of universities}

At present, with the fierce changes of the world, the country and the education, the scientific and connotation development of universities is urgently needed. On the one hand, the world today is in the period with big development, changes and adjustments, to master the international competitive power, countries tend to regard the depth development of human resources, the realization of the development driven by innovation as the strategic choice. The competition between universities in China is becoming increasingly fierce. Facing with new opportunities and new challenges, the key to obtain competitive advantages and grasp the initiative for the universities is to push forward the connotation development of the universities. Party construction in universities plays three main roles in leading school education target, serving the education process and ensuring education direction. The realization of the three main roles is the key to ensure the scientific and connotation development of the universities ${ }^{[5]}$. To achieve three main roles of the party construction in universities, it needs to closely combine with the school characteristics, shape the brand of party construction, strengthen the unique advantages of the brand, and play the demonstration, guidance and radiation role of the brand of party construction.

\section{It is helpful to promote the innovation of grass-roots party construction in universities}

Innovation is the source for the party to maintain vitality and energy. It is a powerful impetus for the party building to keep pace with the times. The brand of party construction work in universities is the banner that leads the innovation and development of party construction work, the continuous vigor and vitality which endow the party construction work. The process of building the brand of grass-roots party construction in universities is the essential process of promoting the continuous innovation of party construction. In this process, it is necessary to constantly emancipate the mind, focus on solving the ideological ideas and contradictory problems that influence and restrict the scientific development of party construction, to promote the innovation of party construction work with innovative ideas. The beneficial practices produced by innovation can make the way of party construction work in universities more scientific, more vigorous and with more energy.

\section{PROBLEMS EXISTING IN BUILDING THE BRAND OF GRASS- ROOTS PARTY CONSTRUCTION IN UNIVERSITIES}

\section{A. Brand recognition is not in place}

Grass-roots party organizations in universities have inadequate understanding and attention on the brand building of party construction. They do not fully understand the connotation of the brand concept of party construction and the content of the construction standards. They do not clearly grasp on how to design the party brand name, how to refine party brand achievements. They do not to regard and grasp the brand building activities of party construction as the effective carrier to improve the whole level of party construction work.

\section{B. Lack of brand innovation concept}

In the brand building of party, it is lack of innovative ideas which are lead and implemented by the innovate methods. The brand building of party construction and the central work of the universities cannot be combined organically with each other. It is lack of summary refinement and sublimation. The brand building of party construction is lack of originality. The activity system is not strong, the brand is not resounding enough, and the features are not obvious enough with less effectiveness ${ }^{[6]}$. Little attention is paid on playing the advantages and functions of the party construction brand. The activities on learning the brand, promoting the brand and improving the brand are not enough. It is not deep enough to exploit the brand connotation and value.

\section{The supporting system needs to be improved}

The main purpose of building the brand of party construction in universities is to improve the scientific level of their party construction with the aim of creating high-quality consciousness. The realization of this purpose cannot be separated from the effective guarantee mechanism. In the process of practice and exploration, it is necessary to perfect the supporting system and corresponding activity mechanism 
of the brand of party construction in universities and colleges which is relative scientific and has strong operational ability.

\section{THE PATH ANALYSIS OF THE BRAND BUILDING OF PARTY CONSTRUCTION IN UNIVERSITIES UNDER MICROSCOPE}

The most enduring meaning of a brand is its value, culture and individuality. The value of the brand of party construction work in universities is to promote the innovation of party construction method and improve the quality and level of educating people through brand construction. The brand culture of party construction in universities is to reveal the party activities, form the culture management mode centered by brand strength and brand value enhancement, create a good party culture atmosphere through the brand construction. The brand personality of the party construction in universities is to actively develop their own cultural resources in the different parts or elements, including the transformation, improvement and innovation of cultural resources and their derivatives based on these through the brand construction, so as to realize its own characteristic resources of the brand. Therefore, the brand construction of the party construction work should start with the value, culture and personality, thus forming the lasting influence of the brand of party construction work.

\section{A. Strengthen brand awareness}

To improve brand consciousness of the school staffs and students especially staffs in party affairs, is the fundamental premise of brand-name construction of grassroots party construction in universities, is also a prerequisite to promoting the value of the brand construction of party construction work in universities. It is important to set the creation of brand as the core goal of the innovation of party construction in universities, so as to guide the development of party construction in universities to the long-term strategy. To regard brand as an important gripper of strengthening and improving party construction work in universities, to lead all party building works in universities. It should be regarded the unified action pointer of all work of party construction to coordinate the relationship between them, to establish the system of party construction with brand strategy as the core. The brand of party construction should be the cohesion to the value orientation and spiritual pursuit of the faculty and students party construction to make them actively participate in, physically take actions, and form a cohesive force and centripetal force of the party in schools.

\section{B. Clear the target position of the brand}

This is the key to construct party building in universities. "Positioning means designing the products and images of the company to take a unique place in the heart of the target market.” [7] In brand construction in party construction, based on the detailed analysis of the schools and the internal and external conditions and environment of CPC party construction, and the advantages and disadvantages of party construction in universities which are found, it needs to clear the target position of the brand, establish brand theme, plot the name and mark of the brand, refine the connotation of the brand.

\section{Implement the project operation}

This is the effective path of the brand construction of party construction. In the process of the brand construction of party construction, it needs to start from the party construction reality in schools, prominent brand personalization and characterization of party construction, establish brand theme, design brand name and logo, and refine the connotation of brand. It needs to use the project management approach in the economic work to regard various party construction brands as a specific project to solve the problems encountered in the party construction. When following the universal law of party construction, schools need to create different brands of party construction, construct different projects, solve different problems, to promote party construction methods more scientific, more targeted.

\section{Build brand image}

This is the important carrier of the brand construction of party construction in universities. As the external features of party construction in universities, the brand image of party construction has the functions to win the trust of the public, improve the cohesive forces of the staff, form a good external environment for the subsistence and development of party construction in universities and improve the brand awareness of party construction in universities ${ }^{[8]}$. Under the premise of well dealing with the relationship between generality and individual character, inheritance of tradition and innovation with times, it needs to integrate various information on the schools and the party construction work in schools, improve the quality and level of education through the formulation of reasonable educational concept, and maintain the old and new university spirit, refine and carry forward the rich individual character and characteristic of school motto, cultivate campus environment with profound cultural background, design brand image to highlight personality and distinctive features, promote brand advantages and so on. It also needs to unity the tangible and intangible party construction and make mutual fusion.

\section{E. Focus on brand promotion}

This is an important guarantee for the brand construction of party construction in universities. It is not enough for a party construction brand project to quickly set up the brand image and education effect by only having a high quality team and high quality of work. It also needs to set up and improve the brand publicity and marketing mechanism of party construction $^{[9]}$. In addition to using newspapers, television, radio and other traditional media to publicize the brand, the micro media which are loved by teachers and students such as We-Chat public number, Microblog, QQ should be made full use of to build new pattern of micro party construction, so as to improve the visibility and reputation of party construction in universities.

\section{CONCLUSION}

In the network "micro" era, the university party construction needs to accurately grasp the laws of time and students growth, cleverly blend brand construction idea into grassroots party construction in universities, constantly promote the scientization, standardization, institutionalization of the grassroots party construction in universities. To explore the theory and path of the construction of the brand of grassroots party construction in universities under "micro" horizon, by strengthening brand awareness, clearing brand 
objects position, implementing project operation, shaping the brand image, paying attention to brand marketing and publicity, to provide new ideas to further strengthen and improve the grass-roots party construction work in universities.

\section{ACKNOWLEDGMENT}

The research work is supported by "the Fundamental Research Funds for the Central Universities”, and the funding project number is: WUT 2017VI120.Thank you for the help of Professor YANG and Professor PENG, Wuhan University of Technology.

\section{REFERENCES}

[1] $\mathrm{Yu} \mathrm{M}$. The innovative research of grass-roots party construction in universities under the new media perspective[J]. Journal of Jiamusi Vocational Institute, 2017.

[2] Gao J L. The Present Situation Problems and Countermeasures of the Grassroots Party Construction in Universities[J]. 2017.
[3] Wang X S. The Innovation of Grass-roots Party Organization Construction in Universities with "Two Learning and One Doing"[J]. Journal of Hebei Energy Institute of Vocation \& Technology, 2017.

[4] Wenbo B O. Using Network Carrier to Build New Mode of Grass-roots Party Construction[J]. Journal of the Party School of Shengli Oilfield, 2016.

[5] Zhang J, Textile S O, University T P. "Internet+Party" Grassroots Party Construction in universities of Innovation and Practice[J]. Education Teaching Forum, 2017.(In Chinese)

[6] Chen J, Qiu Y, Han Z, et al. Research on the theory and practice of service- oriented grassroots party organization construction in universities[J]. Theory Research, 2015.

[7] Jin H. The Theoretical Significance of the Construction of Grass-roots Service Party Organizations in the New Era[J]. Journal of Hubei Correspondence University, 2016.(In Chinese)

[8] Wang F. Review of Research on the Construction of Rural Grass-roots Party Organizations[J]. Journal of Changsha University of Science \& Technology, 2016.

[9] Tang J. The Questions on Rural Grass-roots Party Construction[J]. Journal of the Party School of C.P.C Guilin Municipal Committee, 2015. 